\title{
Chryseobacterium gregarium sp. nov., isolated from decaying plant material
}

\author{
Undine Behrendt, ${ }^{1}$ Andreas Ulrich ${ }^{1}$ and Peter Schumann ${ }^{2}$ \\ ${ }^{1}$ Leibniz-Centre for Agricultural Landscape Research (ZALF), Institute of Landscape Matter \\ Dynamics, Eberswalder Str. 84, D-15374 Müncheberg, Germany \\ ${ }^{2}$ DSMZ-German Collection of Microorganisms and Cell Cultures, Inhoffenstr. 7B, D-38124 \\ Braunschweig, Germany
}

Correspondence Undine Behrendt ubehrendt@zalf.de

\begin{abstract}
In this study, strain $\mathrm{P} 461 / 12^{\top}$, isolated from decaying plant material after mulching a pasture, was shown to represent a novel species of the genus Chryseobacterium by means of a polyphasic approach. The closest phylogenetic neighbours to the novel strain, as determined by $16 \mathrm{~S}$ rRNA gene sequence analysis, were Chryseobacterium daeguense $\mathrm{K} 105^{\top}$ and Chryseobacterium soldanellicola PSD1-4 ${ }^{\top}$ with gene sequence similarities of $97.4 \%$ and $97.2 \%$, respectively. Strain $P 461 / 12^{\top}$ could be differentiated by means of its RiboPrint pattern from the type strains of all recognized Chryseobacterium species belonging to the same cluster as determined by $16 \mathrm{~S}$ rRNA gene sequence comparisons. The nearest phylogenetic neighbours, and in particular the closest relatives $C$. daeguense and $C$. soldanellicola, could be distinguished from the novel isolate by means of several physiological features and also by the remarkably lower proportion of anteiso- $\mathrm{C}_{15: 0}$ in the whole-cell fatty acid profile. Based on these findings, the new isolate represents a novel species, for which the name Chryseobacterium gregarium sp. nov. is proposed. The type strain is $\mathrm{P} 461 / 12^{\top}\left(=\mathrm{DSM} 19109^{\top}=\right.$ LMG $\left.24052^{\top}\right)$.
\end{abstract}

Studies of the composition of the bacterial community in the soil, rhizosphere, phyllosphere and endosphere of plants have shown that strains of the genus Chryseobacterium are indigenous to these habitats (Mahaffee \& Kloepper, 1997; Bacon \& Hinton, 2006; Beattie, 2006). Chryseobacterium indologenes and Chryseobacterium balustinum were the most common species found in several studies (Krechel et al., 2002; Beattie, 2006). In recent years, several novel species isolated from these habitats have been described (Young et al., 2005; Park et al., 2006; Tai et al., 2006; Weon et al., 2006; Behrendt et al., 2007b). Furthermore, studies using newly developed primers have shown that members of the genus Chryseobacterium form a high proportion of the bacterial community of several composts (Green et al., 2006). Investigation of seed and root surfaces of plants growing in soil amended with these composts has revealed a surprising prevalence and diversity of chryseobacteria, indicating that they are major contributors to nutrient cycling in plant environments (Green et al., 2006).

In the context of studying low-intensity forms of grassland use, the effect of mulching treatments on the microflora colonizing the regrowth was investigated in comparison with the mowing of pastures for forage production (Behrendt, 2001). From the decaying grass material produced after mulching, a novel strain, designated

The GenBank/EMBL/DDBJ accession number for the 16S rRNA gene sequence of strain $\mathrm{P} 461 / 12^{\top}$ is $\mathrm{AM} 773820$.
P $461 / 12^{\mathrm{T}}$, was isolated that displayed general characteristics of members of the genus Chryseobacterium (Bernardet et al., 2006). A comparative analysis of the $16 \mathrm{~S}$ rRNA gene sequences indicated that the new strain represented a novel species within this genus. The aim of this study was to determine the precise taxonomic position of the novel strain by using a polyphasic approach.

To study the community structure of culturable heterotrophic bacteria colonizing decaying grass, mulched material was taken from grassland plots as described by Behrendt (2001). The material was cut and homogenized in distilled water by using a Stomacher lab blender and serial dilutions were plated on nutrient agar (SIFIN), supplemented by cycloheximide $\left(0.4 \mathrm{~g} \mathrm{l}^{-1}\right)$. After incubation at $21{ }^{\circ} \mathrm{C}$ for 7 days, a representative number of strains was isolated to determine the community structure. Characterization of a multitude of randomly selected isolates by phenotypic and genetic analysis revealed several strains of unclear taxonomic position. One of these strains, isolate P $461 / 12^{\mathrm{T}}$, was subjected to a detailed taxonomic investigation.

The phylogenetic analysis based on $16 \mathrm{~S}$ rRNA gene sequences was performed as described by Behrendt et al. (2003). Phylogenetic trees were based on a $1411 \mathrm{nt}$ alignment (Escherichia coli positions 39-1445) and constructed using the neighbour-joining (Saitou \& Nei, 1987) and maximum-likelihood (Felsenstein, 1981) algorithms 
(PHYLIP version 3.6; Felsenstein, 1993). As shown in Fig. 1, strain $\mathrm{P} 461 / 12^{\mathrm{T}}$ clustered clearly with the type strain of Chryseobacterium daeguense in both methods of treeing, this was supported by a relatively high bootstrap of $78 \%$ compared with the other species of the genus Chryseobacterium clustering next to the novel isolate. The 16S rRNA gene sequence similarity between strain P $461 / 12^{\mathrm{T}}$ and C. daeguense was $97.4 \%$, followed by $97.2 \%$ similarity to Chryseobacterium soldanellicola. Species that were found in the cluster grouping strain $\mathrm{P} 461 / 12^{\mathrm{T}}$ and $C$. soldanellicola (Fig. 1) showed gene sequence similarity values of $94.5-96.8 \%$. A comparison between the neighbour-joining and the maximum-likelihood tree showed that the positions of several species were not stable in this cluster. However, the 16S rRNA gene sequence similarity of the novel isolate to its closest phylogenetic neighbours fell far below the range of $98.7-99.0 \%$ recommended by Stackebrandt \& Ebers (2006) as the threshold above which DNA-DNA reassociation experiments should be performed in order to confirm the status of a novel species. Thus, the analysis of the 16S rRNA gene sequences demonstrated the separate position of the novel isolate compared with other species of the genus Chryseobacterium.

Ribotyping was also performed to differentiate between the closest phylogenetic neighbours. This fingerprint technique

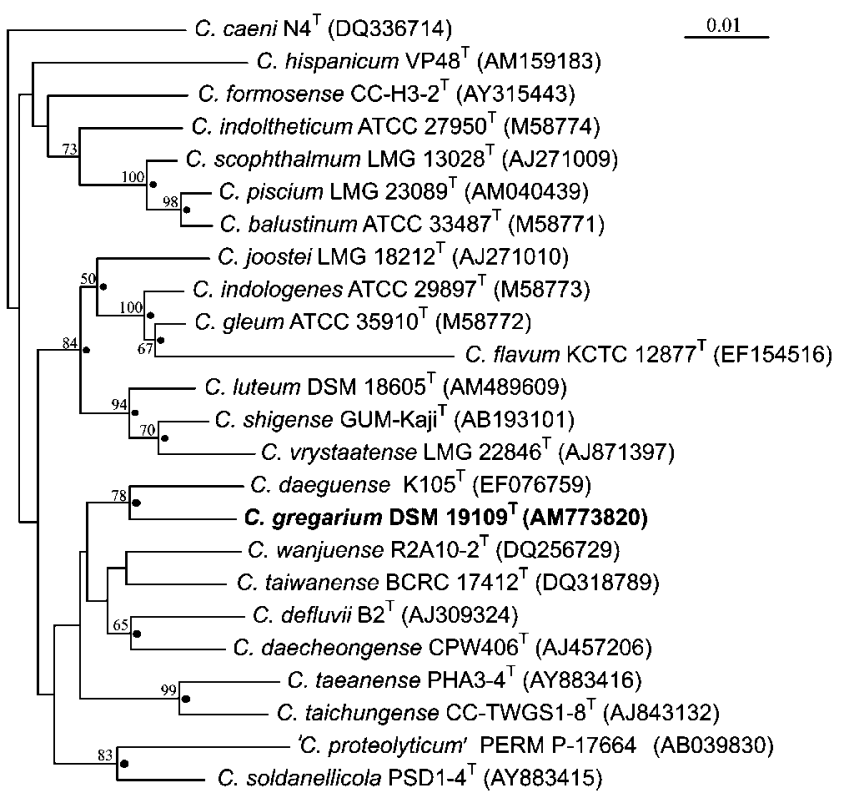

Fig. 1. Neighbour-joining tree showing the relationship of strain $\mathrm{P} 461 / 12^{\top}$ with other species of the genus Chryseobacterium. Filled circles indicate branches of the tree that were also formed by using the maximum-likelihood method (Felsenstein, 1981). Flavobacterium hydatis (GenBank accession no. AM230487) was used as an outgroup (not shown). Numbers at nodes indicate levels of bootstrap support $>50 \%$ based on 1000 resampled datasets. Bar, 0.01 changes per nucleotide position. is based on the analysis of fragments of genomic DNA generated by digestion with restriction endonucleases (e.g. EcoRI, PvuII). The DNA fragments are separated by electrophoresis according to their size, plotted on a nylon membrane and subsequently hybridized with a chemically labelled probe derived from the rRNA operon of Escherichia coli. The bands are detected by using a chemiluminescent substrate and the image of the bands is recorded by a customized charge-coupled device camera (Allerberger \& Fritschel, 1999). It is a sensitive, highly discriminatory technique that is effective for the differentiation of strains. As shown for Elizabethkingia meningoseptica (formerly Chryseobacterium meningosepticum), the use of more than one restriction enzyme has enabled the technique to be used for epidemiological studies (Bernardet et al., 2006). On the other hand, the potential of this technique to differentiate between species with the use of one restriction enzyme has been demonstrated for members of the genus Pseudomonas (Sikorski et al., 2001; Behrendt et al., 2003, 2007a). Strain P $461 / 12^{\mathrm{T}}$ and the type strains of related species that formed the internal cluster in the $16 \mathrm{~S}$ rRNA gene sequence analysis (Fig. 1) were studied by ribotyping with the restriction enzyme EcoRI. The analysis was performed with an automated RiboPrinter microbial characterization system (Qualicon Du Pont). Band patterns were compared using the BioNumerics software (Applied Maths) and clustering was carried out by UPGMA based on Pearson's correlation coefficient (optimization coefficient, 1.2\%). As shown in Fig. 2, the novel isolate was clearly differentiated from the type strains of its nearest phylogenetic neighbours $C$. daeguense and $C$. soldanellicola. Both type strains were grouped in a separate cluster showing a low similarity to strain P $461 / 12^{\mathrm{T}}$. The most similar ribopattern was found for Chryseobacterium daecheongense, which shared $96.1 \% \quad 16 \mathrm{~S}$ rRNA gene sequence similarity with the isolate. However, the dendrogram displayed a higher distance between these strains compared with the distance between the established species Chryseobacterium wanjuense and C. soldanellicola (Fig. 2). Thus, the results of RiboPrinting substantiated the separate species position of the novel isolate as determined by $16 \mathrm{~S}$ rRNA gene sequence analysis.

Morphological and physiological characterization of the novel strain isolated from decaying plant material was performed as described by Behrendt et al. (2007b). Incubation of the API 20NE, API $50 \mathrm{CH}$ and API ZYM test strips (bioMérieux) was performed at $25{ }^{\circ} \mathrm{C}$. The reading of the results of the API $50 \mathrm{CH}$ test strip was postponed to $72 \mathrm{~h}$ as the novel strain showed a delayed reaction. Production of L-phenylalanine deaminase was investigated according to the method of Richard \& Kiredjian (1995). Hydrogen sulphide production was tested on Kligler iron agar (Oxoid) and hydrolysis of Ltyrosine was examined on nutrient agar (SIFIN) supplemented with $0.5 \%(\mathrm{w} / \mathrm{v})$ L-tyrosine. Growth on cetrimide agar was examined on a Pseudomonas agar base with CFC Selective Supplement (Oxoid). All morphological and 


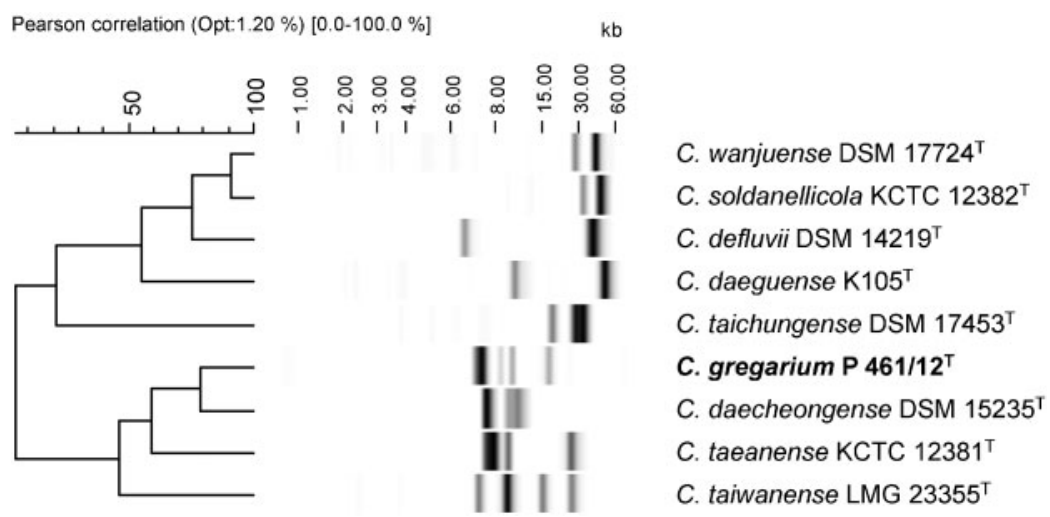

Fig. 2. RiboPrint patterns of EcoRl-restricted DNA of strain $P 461 / 12^{\top}$ and the type strains of related Chryseobacterium species as determined by $16 \mathrm{~S}$ rRNA gene sequence comparisons.

physiological characteristics are given in the species description. As shown in Table 1, selected phenotypic features of strain P $461 / 12^{\mathrm{T}}$ were compared with those of species of the genus Chryseobacterium. Several characteristics for each species were different, which allowed the novel isolate to be distinguished from the recognized species of the genus Chryseobacterium.

The DNA base composition was determined after disruption of bacterial cells by using a French pressure cell. After purification on hydroxyapatite according to the procedure of Cashion et al. (1977), the DNA was degraded to nucleosides by using P1 nuclease and bovine intestinal mucosa alkaline phosphatase as described by Mesbah et al. (1989). The nucleosides were separated by reversed-phase HPLC as described by Tamaoka \& Komagata (1984). The $\mathrm{G}+\mathrm{C}$ content of the DNA of strain $\mathrm{P} 461 / 12^{\mathrm{T}}$ was $38.4 \mathrm{~mol} \%$. This value is at the upper end of the $\mathrm{G}+\mathrm{C}$ content range previously determined for the genus Chryseobacterium as shown in Table 1.

The cellular fatty acid content of cells grown on trypticase soy agar (Merck) for $24 \mathrm{~h}$ at $28{ }^{\circ} \mathrm{C}$ was determined with the Sherlock Microbial Identification system (MIDI version 4.5) as described by Behrendt et al. (1999). The fatty acid profile of strain $\mathrm{P} 461 / 12^{\mathrm{T}}$ consisted of branched fatty acids iso- $\mathrm{C}_{15: 0}(35.1 \%)$, iso- $\mathrm{C}_{17: 1} \omega 9 c(16.9 \%)$, anteiso- $\mathrm{C}_{15: 0}$ $(9.1 \%)$ and iso- $\mathrm{C}_{13: 0}(1.3 \%)$, the hydroxy fatty acids iso$\mathrm{C}_{15: 0} 2-\mathrm{OH}(10.6 \%)$, iso- $\mathrm{C}_{17: 0} 3-\mathrm{OH}(10.0 \%)$, iso- $\mathrm{C}_{15: 0}$ $3-\mathrm{OH}(2.8 \%)$ and $\mathrm{C}_{16: 0} 3-\mathrm{OH}(1.2 \%)$, the unsaturated fatty acid $\mathrm{C}_{18: 1} \omega 5 c(1.2 \%)$ and two unknown fatty acids with equivalent chain lengths (ECL) of $13.565(1.2 \%)$ and $16.582(1.1 \%)$. Furthermore, traces $(<1.0 \%$ of total fatty acids) were found for the straight chain fatty acids $\mathrm{C}_{16: 0}$ and $\mathrm{C}_{14: 0}$, the branched fatty acids iso- $\mathrm{C}_{17: 0}$ and iso- $\mathrm{C}_{16: 0}$, the hydroxy fatty acids $\mathrm{C}_{17: 0} 2-\mathrm{OH}$, iso- $\mathrm{C}_{16: 0} 3-\mathrm{OH}$ and $\mathrm{C}_{15: 0} 2-\mathrm{OH}$, and the unsaturated fatty acid iso- $\mathrm{C}_{17: 1}$. This fatty acid profile was similar to those of other Chryseobacterium species. The presence of large amounts of iso- $\mathrm{C}_{15: 0}$, iso- $\mathrm{C}_{17: 1} \omega 9 c$ and iso- $\mathrm{C}_{17: 0} 3-\mathrm{OH}$ in particular is typical for the genus Chryseobacterium. On the other hand, a relatively high proportion of the fatty acid anteiso$\mathrm{C}_{15: 0}(9.1 \%)$ was found for isolate $\mathrm{P} 461 / 12^{\mathrm{T}}$. This differentiated the novel strain from the nearest phylogenetic neighbours $C$. daeguense and $C$. soldanellicola, which contain traces and $1.9 \%$ of this fatty acid, respectively (Park et al., 2006; Yoon et al., 2007). Furthermore, all other recognized species of the genus Chryseobacterium contain $<4.5 \%$ of anteiso- $\mathrm{C}_{15: 0}$ (Park et al., 2006; Tai et al., 2006; Behrendt et al., 2007b; Quan et al., 2007; Zhou et al., 2007), except Chryseobacterium indoltheticum for which levels of 4.9\% (Quan et al., 2007) and 6.2\% (Tai et al., 2006) of this fatty acid have been reported. Thus, the relatively high proportion of this fatty acid is a further prominent phenotypic feature for the characterization of the novel isolate.

The results of the phylogenetic and phenotypic analyses demonstrate that the new isolate from the decaying plant material does indeed represent a novel species within the genus Chryseobacterium, for which the name Chryseobacterium gregarium sp. nov. is proposed.

\section{Description of Chryseobacterium gregarium sp. nov.}

Chryseobacterium gregarium (gre.ga'ri.um. L. neut. adj. gregarium belonging to the flock/herd; an ordinary species of the genus).

Cells are non-spore-forming, non-motile rods which are $0.6-0.8 \mu \mathrm{m}$ in diameter and $1.5-2.2 \mu \mathrm{m}$ in length and occur singly. They are Gram-negative by classical Gramstaining but the fast $\mathrm{KOH}$ test shows a false Gram-positive reaction. Strictly aerobic. The orange colonies on nutrient agar are smooth with regular margins. Flexirubin type pigments are produced. Slow growth occurs at $4{ }^{\circ} \mathrm{C}$, active growth occurs at $20-30{ }^{\circ} \mathrm{C}$ and no growth occurs at $37{ }^{\circ} \mathrm{C}$. No growth occurs on MacConkey or cetrimide agars. Catalase, oxidase and L-phenylalanine deaminase activities are present, but urease, arginine dihydrolase and DNase activities are absent. Casein, gelatin, starch, Tween 80 and aesculin are hydrolysed, but chitin and L-tyrosine are not. Indole is produced from L-tryptophan. Nitrate and nitrite are not reduced. Hydrogen sulphide is not produced. DGlucose, L-arabinose, D-mannose, D-mannitol, $N$-acetylglucosamine, maltose, potassium gluconate, capric acid, 
Table 1. Differential phenotypic characteristics of species of the genus Chryseobacterium

Species: 1, C. gregarium sp. nov. ( $n=1) ; 2$, C. balustinum $(n=1) ; 3$, C. caeni $(n=1) ; 4$, C. daecheongense $(n=1) ; 5$, C. daeguense ( $n=1) ; 6$, C. defluvii $(n=1) ; 7$, C. flavum $(n=1) ; 8$, C. formosense $(n=1) ; 9$, C. gleum $(n=2) ; 10$, C. hispanicum $(n=1) ; 11$, C. indologenes $(n=7) ; 12$, C. indoltheticum $(n=1) ; 13$, C. joostei $(n=11) ; 14$, C. luteum $(n=3) ; 15$, C. piscium $(n=4) ; 16$, 'C. proteolyticum' $(n=2) ; 17$, C. scophthalmum ( $n=2) ; 18, C$. shigense $(n=1) ; 19, C$. soldanellicola $(n=1) ; 20$, C. taeanense $(n=1) ; 21$, C. taichungense $(n=1) ; 22, C$. taiwanense $(n=1) ; 23, C$. vrystaatense $(n=36) ; 24, C$. wanjuense $(n=1)$. Data from Mudarris et al. (1994), Yamaguchi \& Yokoe (2000), Hugo et al. (2003), Kämpfer et al. (2003), de Beer et al. (2005), Kim et al. (2005), Shen et al. (2005), Shimomura et al. (2005), Young et al. (2005), de Beer et al. (2006), Gallego et al. (2006), Park et al. (2006), Tai et al. (2006), Weon et al. (2006), Behrendt et al. (2007b), Quan et al. (2007), Yoon et al. (2007), Zhou et al. (2007) and this study. +, Positive; -, negative; W, weak reaction; $\mathrm{D}$, delayed reaction; $\mathrm{v}$, variable; ND, no data available.

\begin{tabular}{|c|c|c|c|c|c|c|c|c|c|c|c|c|c|c|c|c|c|c|c|c|c|c|c|c|}
\hline Characteristic & 1 & 2 & 3 & 4 & 5 & 6 & 7 & 8 & 9 & 10 & 11 & 12 & 13 & 14 & 15 & 16 & 17 & 18 & 19 & 20 & 21 & 22 & 23 & 24 \\
\hline \multicolumn{25}{|l|}{ Growth at: } \\
\hline $5{ }^{\circ} \mathrm{C}$ & $\mathrm{D}$ & $\mathrm{D}$ & + & - & - & - & + & - & - & $\mathrm{D}$ & - & + & + & $\mathrm{D}$ & + & $\mathrm{ND}$ & $\mathrm{D}$ & + & + & + & - & + & + & + \\
\hline $37{ }^{\circ} \mathrm{C}$ & - & + & + & + & + & + & + & - & + & - & $\mathrm{V}^{*}$ & $\mathrm{~V}^{*}$ & - & - & - & + & - & - & + & + & + & + & - & + \\
\hline \multicolumn{25}{|l|}{ Growth on: } \\
\hline MacConkey agar & - & + & - & - & - & - & + & - & + & - & $\mathrm{V}$ & + & + & - & - & - & - & - & - & - & - & $\mathrm{ND}$ & - & W \\
\hline Cetrimide agar & - & - & $\mathrm{ND}$ & $\mathrm{ND}$ & $\mathrm{ND}$ & - & + & $\mathrm{ND}$ & - & $\mathrm{ND}$ & + & - & + & - & - & $\mathrm{ND}$ & - & $\mathrm{ND}$ & - & - & $\mathrm{ND}$ & - & + & $\mathrm{ND}$ \\
\hline \multicolumn{25}{|l|}{ Activity of: } \\
\hline Urease & - & - & + & - & - & - & - & - & $\mathrm{V}$ & - & - & - & $\mathrm{V}$ & - & + & - & + & - & - & - & - & - & + & - \\
\hline $\begin{array}{l}\text { Phenylalanine } \\
\text { deaminase }\end{array}$ & + & - & $\mathrm{ND}$ & $\mathrm{ND}$ & $\mathrm{ND}$ & - & $\mathrm{ND}$ & ND & - & $\mathrm{ND}$ & - & + & - & - & + & - & - & ND & - & + & $\mathrm{ND}$ & + & - & $\mathrm{ND}$ \\
\hline \multicolumn{25}{|l|}{ Production of: } \\
\hline $\mathrm{H}_{2} \mathrm{~S}$ & - & - & - & - & - & - & - & - & - & - & - & + & - & - & - & $\mathrm{w}$ & - & - & - & - & - & - & $\mathrm{v}$ & $\mathrm{ND}$ \\
\hline Indole & - & + & - & - & - & + & - & + & + & w & + & + & + & - & + & + & - & + & - & - & $\mathrm{W}$ & - & + & - \\
\hline \multicolumn{25}{|l|}{ Reduction of: } \\
\hline Nitrate & - & + & - & + & - & - & - & - & $\mathrm{V}$ & + & $\mathrm{V}$ & - & - & - & + & - & - & - & - & - & - & + & - & - \\
\hline Nitrite & - & - & - & - & - & $\mathrm{ND}$ & - & $\mathrm{ND}$ & + & + & - & - & - & - & - & - & - & ND & - & - & $\mathrm{ND}$ & - & + & $\mathrm{ND}$ \\
\hline \multicolumn{25}{|c|}{ Acid production from: } \\
\hline L-Arabinose & + & - & - & - & $\mathrm{W}$ & - & $\mathrm{ND}$ & - & $\mathrm{v}$ & + & - & - & - & + & $\mathrm{ND}$ & + & - & - & - & - & - & + & $\mathrm{ND}$ & - \\
\hline D-Cellobiose & - & + & $\mathrm{ND}$ & + & - & $\mathrm{w}$ & - & - & - & $\mathrm{ND}$ & - & - & - & - & $\mathrm{ND}$ & - & + & $\mathrm{ND}$ & $\mathrm{ND}$ & $\mathrm{ND}$ & - & + & $\mathrm{ND}$ & - \\
\hline D-Fructose & - & + & - & + & + & + & + & ND & + & + & $\mathrm{D}$ & - & + & + & $\mathrm{ND}$ & $\mathrm{ND}$ & - & + & - & - & ND & $\mathrm{V}$ & $\mathrm{ND}$ & - \\
\hline D-Glucose & + & + & - & - & + & + & - & $\mathrm{w}$ & + & + & + & + & + & + & $\mathrm{ND}$ & + & + & + & $\mathrm{ND}$ & $\mathrm{ND}$ & $\mathrm{w}$ & $\mathrm{ND}$ & $\mathrm{ND}$ & + \\
\hline Glycerol & - & - & - & + & - & + & $\mathrm{ND}$ & - & + & + & $\mathrm{D}$ & - & $\mathrm{V}$ & + & $\mathrm{ND}$ & $\mathrm{W}$ & - & - & - & - & $\mathrm{ND}$ & - & $\mathrm{ND}$ & - \\
\hline Maltose & + & - & - & - & + & + & + & - & + & + & + & + & + & + & $\mathrm{ND}$ & + & - & - & - & - & + & $\mathrm{ND}$ & $\mathrm{ND}$ & - \\
\hline Salicin & + & - & $\mathrm{ND}$ & - & - & - & - & $\mathrm{ND}$ & - & $\mathrm{ND}$ & - & - & - & + & $\mathrm{ND}$ & - & + & $\mathrm{ND}$ & $\mathrm{ND}$ & $\mathrm{ND}$ & - & $\mathrm{ND}$ & $\mathrm{ND}$ & - \\
\hline Sucrose & + & - & - & - & - & - & - & - & - & $\mathrm{ND}$ & - & - & - & + & $\mathrm{ND}$ & + & + & $\mathrm{ND}$ & $\mathrm{ND}$ & $\mathrm{ND}$ & - & - & $\mathrm{ND}$ & - \\
\hline Trehalose & + & - & - & + & + & + & + & + & + & - & + & - & + & + & $\mathrm{ND}$ & + & + & - & - & - & + & - & $\mathrm{ND}$ & + \\
\hline D-Xylose & - & - & - & + & $\mathrm{w}$ & - & + & $\mathrm{w}$ & V & + & - & - & - & - & $\mathrm{ND}$ & $\mathrm{ND}$ & - & - & - & - & + & $\mathrm{ND}$ & $\mathrm{ND}$ & - \\
\hline \multicolumn{25}{|l|}{ Hydrolysis of: } \\
\hline $\begin{array}{l}\text { 2-Naphthyl } \\
\text { butyrate }\end{array}$ & + & - & + & - & + & $\mathrm{w}$ & $\mathrm{ND}$ & + & - & + & - & - & - & - & $\mathrm{ND}$ & $\mathrm{ND}$ & + & ND & + & + & + & - & $\mathrm{ND}$ & w \\
\hline $\begin{array}{l}N \text {-Benzoyl-DL- } \\
\text { arginine 2- } \\
\text { naphthylamide }\end{array}$ & - & - & - & - & - & + & $\mathrm{ND}$ & + & - & + & - & - & + & + & $\mathrm{ND}$ & $\mathrm{ND}$ & + & ND & - & - & + & - & $\mathrm{ND}$ & - \\
\hline $\begin{array}{l}\text { 2-Naphthyl } \beta \text {-D- } \\
\text { galactopyrano- } \\
\text { side }\end{array}$ & - & - & - & - & - & - & $\mathrm{ND}$ & - & - & - & - & - & - & + & $\mathrm{ND}$ & $\mathrm{ND}$ & - & ND & - & - & $\mathrm{w}$ & - & ND & - \\
\hline $\begin{array}{l}\text { 2-Naphthyl } \alpha \text {-D- } \\
\text { glucopyranoside }\end{array}$ & $\mathrm{w}$ & - & - & - & + & + & $\mathrm{ND}$ & - & + & + & + & + & + & + & $\mathrm{ND}$ & $\mathrm{ND}$ & - & $\mathrm{ND}$ & + & + & + & + & $\mathrm{ND}$ & $\mathrm{w}$ \\
\hline $\begin{array}{l}\text { 6-Bromo-2- } \\
\text { naphthyl } \beta \text {-D- } \\
\text { glucopyranoside }\end{array}$ & + & - & + & - & - & - & $\mathrm{ND}$ & + & + & + & - & - & - & + & $\mathrm{ND}$ & $\mathrm{ND}$ & + & ND & - & + & + & - & $\mathrm{ND}$ & - \\
\hline DNA & - & + & $\mathrm{ND}$ & $\mathrm{ND}$ & + & $\mathrm{ND}$ & - & $\mathrm{ND}$ & + & - & + & + & + & - & + & + & + & ND & - & - & $\mathrm{ND}$ & $\mathrm{ND}$ & + & $\mathrm{w}$ \\
\hline Starch & + & - & - & + & + & + & $\mathrm{ND}$ & $\mathrm{ND}$ & + & + & + & - & + & + & - & + & - & + & $\mathrm{ND}$ & $\mathrm{ND}$ & $\mathrm{ND}$ & + & - & + \\
\hline Tween 80 & + & + & - & - & + & $\mathrm{ND}$ & + & - & + & - & + & + & + & $\mathrm{V}$ & $\mathrm{V}$ & + & + & ND & - & + & ND & + & + & $\mathrm{ND}$ \\
\hline Tyrosine & - & - & $\mathrm{ND}$ & $\mathrm{ND}$ & + & + & + & $\mathrm{ND}$ & + & $\mathrm{ND}$ & - & $\mathrm{D}$ & + & - & - & + & + & ND & - & - & $\mathrm{ND}$ & - & - & + \\
\hline DNA G $+C(\mathrm{~mol} \%)$ & 38.4 & 33.1 & 38.2 & 36.63 & 36.8 & 38.8 & 37.2 & ND & 38.0 & 34.3 & 38.5 & 33.8 & 36.83 & $38.7 \dagger$ & 33.6 & 37.1 & 34.2 & 36.62 & 28.8 & 32.1 & $\mathrm{ND}$ & 36.8 & 37.1 & 37.8 \\
\hline
\end{tabular}

${ }^{\star}$ Different reactions given by the authors.

$\dagger$ Determined for the type strain DSM $18605^{\mathrm{T}}$. 
adipic acid, malic acid, trisodium citrate and phenylacetic acid are not assimilated in the API 20NE strip. Oxidative acid production occurs in the API $50 \mathrm{CH}$ strip for Larabinose, D-ribose, D-glucose, D-mannose, amygdalin, arbutin, salicin, maltose, D-lactose, sucrose, trehalose and gentiobiose, while oxidative acid production does not occur for glycerol, erythritol, D-arabinose, D- and L-xylose, $\mathrm{D}$-adonitol, methyl $\beta$-D-xylopyranoside, D-galactose, Dfructose, L-sorbose, L-rhamnose, dulcitol, inositol, Dmannitol, D-sorbitol, methyl $\alpha$-D-mannopyranoside, methyl $\alpha$-D-glucopyranoside, $N$-acetylglucosamine, D-cellobiose, melibiose, inulin, melezitose, raffinose, starch, glycogen, xylitol, D-turanose, D-lyxose, D-tagatose, D- and L-fucose, D- and L-arabitol, potassium gluconate, potassium 2-ketogluconate and potassium 5-ketogluconate. Activity on the API ZYM strip is observed for alkaline phosphatase, leucine arylamidase, acid phosphatase, naphthol-AS-BIphosphohydrolase, $\beta$-glucosidase and $N$-acetyl glucosamidase. No activity is found for esterase (C4), lipase (C14), cystine arylamidase, trypsin, chymotrypsin, $\alpha$-galactosidase, $\beta$-galactosidase, $\beta$-glucuronidase, $\alpha$-mannosidase or $\alpha$-fucosidase. The reaction for esterase lipase (C8), valine arylamidase and $\alpha$-glucosidase is weak. The main fatty acids $(>9 \%)$ are iso- $\mathrm{C}_{15: 0}$, iso- $\mathrm{C}_{17: 1} \omega 9 c$, iso- $\mathrm{C}_{15: 0} 2-\mathrm{OH}$, iso$\mathrm{C}_{17: 0} 3-\mathrm{OH}$ and anteiso- $\mathrm{C}_{15: 0}$. The DNA G $+\mathrm{C}$ content of the type strain is $38.4 \mathrm{~mol} \%$.

The type strain, $\mathrm{P} 461 / 12^{\mathrm{T}}\left(=\mathrm{DSM} 19109^{\mathrm{T}}=\mathrm{LMG} 24052^{\mathrm{T}}\right)$, was isolated from decaying plant material in Paulinenaue (Germany).

\section{Acknowledgements}

We wish to thank Mrs B. Selch, Mrs S. Weinert (ZALF-Müncheberg) and Mrs G. Pötter (DSMZ-Braunschweig) for their excellent technical assistance. We thank J.-H. Yoon (Korea Research Institute of Bioscience and Biotechnology, Laboratory of Microbial Function) and S. B. Kim (Department of Microbiology, School of Bioscience and Biotechnology, Chungnam National University, Korea) for providing us with strains. Furthermore, we would like to acknowledge Dr H. G. Trüper (Rheinische Friedrich-Wilhelm-Universität, Bonn) for his help with the Latin construction of the species name.

\section{References}

Allerberger, F. \& Fritschel, S. J. (1999). Use of automated ribotyping of Austrian Listeria monocytogenes isolates to support epidemiological typing. J Microbiol Methods 35, 237-244.

Bacon, C. W. \& Hinton, D. M. (2006). Bacterial endophytes: the endophytic niche, its occupants, and its utility. In Plant-Associated Bacteria, pp. 155-194. Edited by S. S. Gnanamanickam. Dordrecht, The Netherlands: Springer.

Beattie, G. A. (2006). Plant-associated bacteria: survey, molecular phylogeny, genomics and recent advances. In Plant-Associated Bacteria, pp. 1-56. Edited by S. S. Gnanamanickam. Dordrecht, The Netherlands: Springer.

Behrendt, U. (2001). Der Einflu $\beta$ differenzierter Bewirtschaftungsintensität von Niedermoorgrünland auf die Entwicklung von Mikroorganismen-Gesellschaften in der Phyllosphäre von Gräsern. Nr.
45, Müncheberg: Zentrum für Agrarlandschafts- und Landnutzungsforschung (ZALF) e.V.

Behrendt, U., Ulrich, A., Schumann, P., Erler, W., Burghardt, J. \& Seyfarth, W. (1999). A taxonomic study of bacteria isolated from grasses: a proposed new species Pseudomonas graminis sp. nov. Int $J$ Syst Bacteriol 49, 297-308.

Behrendt, U., Ulrich, A. \& Schumann, P. (2003). Fluorescent pseudomonads associated with the phyllosphere of grasses; Pseudomonas trivialis sp. nov., Pseudomonas poae sp. nov. and Pseudomonas congelans sp. nov. Int J Syst Evol Microbiol 53, 1461-1469.

Behrendt, U., Ulrich, A., Schumann, P., Meyer, J.-M. \& Spröer, C. (2007a). Pseudomonas lurida sp. nov., a fluorescent species associated with the phyllosphere of grasses. Int J Syst Evol Microbiol 57, 979-985.

Behrendt, U., Ulrich, A., Schumann, P. \& Spröer, C. (2007b). Chryseobacterium luteum sp. nov., a bacterium associated with the phyllosphere of grasses. Int J Syst Evol Microbiol 57, 1881-1885.

Bernardet, J.-F., Hugo, C. J. \& Bruun, B. (2006). The Genera Chryseobacterium and Elizabethkingia. In The Prokaryotes, a Handbook on the Biology of Bacteria, 3rd edn, vol. 7, pp. 638-676. Edited by M. Dworkin. New York: Springer.

Cashion, P., Holder-Franklin, M. A., McCully, J. \& Franklin, M. (1977). A rapid method for base ratio determination of bacterial DNA. Anal Biochem 81, 461-466.

de Beer, H., Hugo, C. J., Jooste, P. J., Willems, A., Vancanneyt, M., Coenye, T. \& Vandamme, P. A. R. (2005). Chryseobacterium vrystaatense sp. nov., isolated from raw chicken in a chickenprocessing plant. Int J Syst Evol Microbiol 55, 2149-2153.

de Beer, H., Hugo, C. J., Jooste, P. J., Vancanneyt, M., Coenye, T. \& Vandamme, P. (2006). Chryseobacterium piscium sp. nov., isolated from fish of the South Atlantic Ocean off South Africa. Int J Syst Evol Microbiol 56, 1317-1322.

Felsenstein, J. (1981). Evolutionary tree from DNA sequences: a maximum likelihood approach. J Mol Evol 17, 368-376.

Felsenstein, J. (1993). PHYLIP (phylogeny inference package), version 3.5c. Distributed by the author. Department of Genome Sciences, University of Washington, Seattle, USA.

Gallego, V., Garcia, M. T. \& Ventosa, A. (2006). Chryseobacterium hispanicum sp. nov., isolated from the drinking water distribution system of Sevilla, Spain. Int J Syst Evol Microbiol 56, 1589-1592.

Green, S. J., Inbar, E., Michel, F. C., Jr, Hadar, Y. \& Minz, D. (2006). Succession of bacterial communities during early plant development: transition from seed to root and effect of compost amendment. Appl Environ Microbiol 72, 3975-3983.

Hugo, C. J., Segers, P., Hoste, B., Vancanneyt, M. \& Kersters, K. (2003). Chryseobacterium joostei sp. nov., isolated from the dairy environment. Int J Syst Evol Microbiol 53, 771-777.

Kämpfer, P., Dreyer, U., Neef, A., Dott, W. \& Busse, H.-J. (2003). Chryseobacterium defluvii sp. nov., isolated from wastewater. Int J Syst Evol Microbiol 53, 93-97.

Kim, K. K., Bae, H.-S., Schumann, P. \& Lee, S.-T. (2005). Chryseobacterium daecheongense sp. nov., isolated from freshwater lake sediment. Int J Syst Evol Microbiol 55, 133-138.

Krechel, A., Faupel, A., Hallmann, J., Ulrich, A. \& Berg, G. (2002). Potato-associated bacteria and their antagonistic potential towards plant-pathogenic fungi and the plant-parasitic nematode Meloidogyne incognita (Kofoid \& White) Chitwood. Can J Microbiol 48, 772-786.

Mahaffee, W. F. \& Kloepper, J. W. (1997). Temporal changes in the bacterial communities of soil, rhizosphere, and endorhiza associated with field-grown cucumber (Cucumis sativus L.). Microb Ecol 34, 210-223. 
Mesbah, M., Premachandran, U. \& Whitman, W. B. (1989). Precise measurement of the $\mathrm{G}+\mathrm{C}$ content of deoxyribonucleic acid by high-performance liquid chromatography. Int J Syst Bacteriol 39, 159-167.

Mudarris, M., Austin, B., Segers, P., Vancanneyt, M., Hoste, B. \& Bernardet, J. F. (1994). Flavobacterium scophthalmum sp. nov., a pathogen of turbot (Scophthalmus maximus L.). Int J Syst Bacteriol 44, 447-453.

Park, M. S., Jung, S. R., Lee, K. H., Lee, M.-S., Do, J. O., Kim, S. B. \& Bae, K. S. (2006). Chryseobacterium soldanellicola sp. nov. and Chryseobacterium taeanense sp. nov., isolated from roots of sand-dune plants. Int J Syst Evol Microbiol 56, 433-438.

Quan, Z.-X., Kim, K. K., Kim, M.-K., Jin, L. \& Lee, S.-T. (2007). Chryseobacterium caeni sp. nov., isolated from bioreactor sludge. Int $J$ Syst Evol Microbiol 57, 141-145.

Richard, C. \& Kiredjian, M. (1995). Laboratory Methods for the Identification of Strictly Aerobic Gram-Negative Bacilli. Paris, France: Institut Pasteur.

Saitou, N. \& Nei, M. (1987). The neighbor-joining method: a new method for reconstructing phylogenetic trees. Mol Biol Evol 4, 406-425.

Shen, F.-T., Kämpfer, P., Young, C.-C., Lai, W.-A. \& Arun, A. B. (2005). Chryseobacterium taichungense sp. nov., isolated from contaminated soil. Int J Syst Evol Microbiol 55, 1301-1304.

Shimomura, K., Kaji, S. \& Hiraishi, A. (2005). Chryseobacterium shigense sp. nov., a yellow-pigmented, aerobic bacterium isolated from a lactic acid beverage. Int J Syst Evol Microbiol 55, 1903-1906.
Sikorski, J., Stackebrandt, E. \& Wackernagel, W. (2001). Pseudomonas kilonensis sp. nov., a bacterium isolated from agricultural soil. Int J Syst Evol Microbiol 51, 1549-1555.

Stackebrandt, E. \& Ebers, J. (2006). Taxonomic parameters revisited: tarnished gold standards. Microbiol Today 33, 152-155.

Tai, C.-J., Kuo, H.-P., Lee, F.-L., Chen, H.-K., Yokota, A. \& Lo, C.-C. (2006). Chryseobacterium taiwanense sp. nov., isolated from soil in Taiwan. Int J Syst Evol Microbiol 56, 1771-1776.

Tamaoka, J. \& Komagata, K. (1984). Determination of DNA base composition by reversed-phase high-performance liquid chromatography. FEMS Microbiol Lett 25, 125-128.

Weon, H.-Y., Kim, B.-Y., Yoo, S.-H., Kwon, S.-W., Cho, Y.-H., Go, S.-J. \& Stackebrandt, E. (2006). Chryseobacterium wanjuense sp. nov., isolated from greenhouse soil in Korea. Int J Syst Evol Microbiol 56, 1501-1504.

Yamaguchi, S. \& Yokoe, M. (2000). A novel protein-deamidating enzyme from Chryseobacterium proteolyticum sp. nov., a newly isolated bacterium from soil. Appl Environ Microbiol 66, 3337-3343.

Yoon, J.-H., Kang, S.-J. \& Oh, T.-K. (2007). Chryseobacterium daeguense sp. nov., isolated from wastewater of a textile dye works. Int J Syst Evol Microbiol 57, 1355-1359.

Young, C.-C., Kämpfer, P., Shen, F.-T., Lai, W.-A. \& Arun, A. B. (2005). Chryseobacterium formosense sp. nov., isolated from the rhizosphere of Lactuca sativa L. (garden lettuce). Int J Syst Evol Microbiol 55, 423-426.

Zhou, Y., Dong, J., Wang, X., Huang, X., Zhang, K.-Y., Zhang, Y.-Q., Guo, Y.-F., Lai, R. \& Li, W.-J. (2007). Chryseobacterium flavum sp. nov., isolated from polluted soil. Int J Syst Evol Microbiol 57, 1765-1769. 